\title{
Under Duress \\ Suppressing and Recovering Memories of the Indonesian Sixties
}

From October 1965, the Indonesian Communist Party (Partai Komunis Indonesia, or PKI) and its followers were brutally repressed after the party's alleged involvement in a coup attempt. Approximately half a million party members and sympathizers were killed, and hundreds of thousands of them were imprisoned for varying lengths of time. This paper examines how collective memory and a sense of identity were shaped under the conditions of repression and silence that the Suharto regime (1966-1998) imposed on former political prisoners in Indonesia. The survival strategies employed by some former political prisoners, such as assuming new names and new lives, helped obscure the past. In attempting to reconstruct the 1960s as a period of political activism, an obstacle for the researcher has also been the respondents' difficulties in remembering, as those performing the act of remembering were accustomed to denying and downplaying their political past. At the same time, the regime's persecution of this group has fostered a community united by a common grievance, and created the outlines of a shared collective memory. Based on research conducted in Indonesia, I reflect on the challenges for oral historians in analyzing memories that have long been suppressed. 
Oei Hiem Hwie is a former political prisoner who was imprisoned under Suharto's New Order regime for thirteen years. Born in 1935, Oei was a journalist for the East Javanese newspaper Trompet Masjarakat (People's Bugle), which the army banned in 1965 for being a pro-communist publication. An avid reader and collector of books from a young age, Oei lost some of his collection in the 1965-1966 repression of the Indonesian Communist Party (Partai Komunis Indonesia, or PKI). After the fall of the regime, Oei began running the Medayu Agung Library in Surabaya, with specialist collections on the Indonesian ethnic Chinese, and books and magazines from the 1950s and the 1960s, partly drawn from his own collection (Graham 2004). In 2007, Oei only reluctantly agreed for me to interview him for my research on the violent transition to the Suharto regime, because he felt deeply traumatized by his imprisonment and his memories of living through the 1965-1966 mass killings. He was uncertain if he was prepared to revisit his memories of the period.

In this article, I explore the effects of decades-long government policies and social attitudes on the memories and understanding of historical events surrounding the violent transition to Suharto rule in Indonesia. How are survivors' memories affected by the public history that provides the dominant narrative of these events? I reflect on how government policies and social attitudes have molded ways of remembering.

Many forms of political and social activism were destroyed through the repression of the PKI. The party is still banned today. In this context, how do former activists recall this "problematic" past? In view of the Suharto regime's strong control of the production and narration of history for more than thirty years, and of restrictions on the victims' ability to counter this history, a key problem in Indonesia has been how to narrate past political activism. I explore the need for space for a multiplicity of narratives, given the complex nature of violence and its aftermath, the diverse types of activism in which the Indonesian Left was engaged in the 1960s, and large number of former political prisoners who are spread across the archipelago.

In interviewing over thirty former political prisoners, my research has attempted to weave alternative narratives of the 1950s and 1960s, as well as examine the difficulties of the transition to New Order rule. My article reflects on methodological issues in working with memories and life story interviews that potentially apply to other contexts beyond Indonesia. The study relied on interviews due to the lack of written 
records describing the kinds of political repression against the Left. Records, even newspaper articles, couch the repression in veiled terms and do not accurately reflect the ferocity of the physical campaign against the PKI in the mid- to late 1960s.

Memories of the 1960s among survivors of the violence remain fragmentary due to the length of time that has lapsed. The pool of potential interviewees has slowly shrunk as a result of age, in accordance with Robert Cribb's $(2002,563)$ prediction that there would be a "brief window" (until 2010) to gather material on the 1965-1966 mass killings before the main protagonists died or became senile. On the individual level, trauma affects some interviewees' ability to recall and convey their recollections (Jelin 2003). Trauma affects interviewees' modes of articulating their experiences, to the extent that language and representation are inimical to traumatic experiences (Leydesdorff et al. 1999, 1; cf. Gilmore 2001, 7). Dori Laub $(1995,64)$ has termed this "the impossibility of telling" in the context of the Holocaust, in that witnesses could not express what they saw to others until many years later. Besides the social and legal restrictions the regime placed on former political prisoners, memories also slowly lose their edge and color when they are not actively recalled and discussed with others or publicly. Individual memories are, after all, always socially framed (Halbwachs 1992, 53).

Individual memory is a part of group memory, in that remembering "is connected with the thoughts that come to us from the social milieu"; hence, the collective (ibid.). Maurice Halbwachs (ibid., 52) theorized that memories are "localized" within the context of the groups we belong to, such as the family and religious community. Remembering is based on fragments, scraps of memory-in other words, it is an act of reconstruction in the present, rather than the resurrection of the past (Whitehead 2009, 126). As distinct from history, collective memory "is a current of continuous thought whose continuity is not at all artificial, for it retains from the past only what still lives or is capable of living in the consciousness of the groups keeping the memory alive" (Halbwachs 2007,140). Pierre Nora (1996) agrees with Halbwachs on this distinction between memory and history, which he argues are "in many respects opposed." Nora (ibid., 3) writes that memory is "capable of lying dormant for long periods only to be suddenly reawakened." Nora's suggestion holds true to a certain extent, but memories "under duress" that have had to be partially or wholly concealed for many years and little discussed with others, suffer by losing their sharpness 
by virtue of their lack of sociality. By sociality, I mean the notion that memories we hold are checked and revised against those of others around us.

\section{INDONESIA UNDER SUKARNO}

Indonesians won independence from the Dutch colonial rulers in 1949. They had fought a four-year struggle against the Dutch from 1945 to 1949, forcing the Dutch in the end to concede at the negotiating table. Indonesians were buoyed by their victory over the Dutch, in spite of the difficulties at the beginning of independence. Infrastructure was destroyed in the conflict. The key sectors of the economy were still in Dutch companies' hands, and up to half of the population were illiterate ${ }^{1}$ (Kementerian Pendidikan dan Kebudajaan 1952,2).

Under President Sukarno, Indonesia became a leading light in campaigning for the right to self-determination. The Bandung Asia Africa conference in 1955 remains an example of multilateral diplomacy. The conference aimed to push for decolonization, and was an attempt by countries in the Asian and Africa regions to steer a different course in the context of the polarization of the Cold War. Following the conference, organizations arose, inspired by the spirit of Bandung, including the Afro-Asian People's Solidarity Organization (AAPSO) and a range of other profession-based Afro-Asian groupings, such as writers, lawyers, and journalists. Many Indonesians went overseas as part of cultural, academic, professional, diplomatic, and military exchanges (Hill 2010). Indonesian women, first in the Indonesian Women's Congress (Kongres Wanita Indonesia, or Kowani), then through the Indonesian Women's Movement (Gerakan Wanita Indonesia, or Gerwani), ${ }^{2}$ participated in the Women's International Democratic Federation (Martyn 2005, 157). As the Cold War wore on, however, Indonesia was pressured to choose a side, and was at the same time blighted by regional rebellions and a stagnating economy. Afro-Asian solidarity was becoming complicated by skirmishes that developed between Afro-Asian countries themselves, such as India and Pakistan. The Non-Aligned Movement (NAM), which arose in 1961 in Belgrade, also created different alliances compared to Bandung, such as in the exclusion of China from NAM. ${ }^{3}$

Sukarno spoke out against imperialism and formulated new concepts in describing the forces in world politics in the early 1960s, 
such as "Nefos" (new emerging forces) and "Oldefos" (old established forces). His opposition to imperialism, which was not necessarily shared by all sectors of society in Indonesia, reduced Indonesia's relationships with Western powers-such as the United States, Great Britain, and the Netherlands- to tatters. Indonesia was embroiled in conflict with the Dutch, who insisted on holding on to West Irian after the transfer of sovereignty in 1949. Sukarno opposed the British founding of the state of Malaysia, which he viewed as a neocolonial construct on Indonesia's doorstep. In contrast, Indonesia had a close relationship with the communist bloc, especially China. In 1965, the PKI was the third largest communist party in the world and a China supporter in the Sino-Soviet split. The PKI claimed influence over 27 million people, 3.5 million in the party itself and the rest in mass organizations in which it had a measure of political leadership (Aidit 1965, cited in Mortimer 1974, 368). These organizations included the trade union federation, the All-Indonesia Central Workers' Organization (Sentra Organisasi Buruh Seluruh Indonesia, or SOBSI), Gerwani and a number of student, professional, and peasant associations. Indonesia's role internationally in the 1950s and 1960s, both on the state and civil society levels, is little appreciated today, because of the association of this past with Sukarno and the Indonesian Left.

\section{THIRTIETH SEPTEMBER MOVEMENT AND THE RISE OF THE NEW ORDER REGIME}

Events from 30 September to 1 October 1965 proved decisive in discrediting the Left for decades to come. On 30 September 1965, seven army officers, including six generals, were kidnapped from homes in Jakarta and killed on the outskirts of the city at Lubang Buaya, by a group that called itself the Thirtieth September Movement. The group was led by Lieutenant Colonel Untung of the Cakrabirawa Palace Guards. Those involved in the Movement argued that they were trying to safeguard President Sukarno from a right-wing, United-Statesbacked Council of Generals. There are many theories about the nature of the Movement, which was led by a group of leftist military officers, and the level of involvement of the PKI within it (e.g., Anderson and McVey 1971; Wertheim 1970; Crouch 1988; Roosa 2006). Historian John Roosa $(2006,174)$ — in the most recent contribution to the scholarship, conducted through archival research and, for the 
first time, interviews with those on the PKI side-contended that most of the PKI membership and leadership had no knowledge of the PKI's involvement in the Movement; instead Roosa finds that the PKI was implicated in the Movement through its Special Bureau, a section of the party that liaised with sympathetic military officers, which came under the direct supervision of PKI chairman D. N. Aidit. Within the heightening political tensions and rivalries in Indonesia in the mid-1960s, and with Sukarno's growing ill health, Aidit had favored a military solution, as represented by the Thirtieth September Movement, in dealing with the threat that the army posed to the PKI.

In response, Major General Suharto, who was then the head of the Kostrad (Komando Strategis Angkatan Darat, or the Army Strategic Reserve Command), took swift action to outmanoeuvre leaders of the Movement and attack the PKI at the same time. The army under Suharto labeled the events at Lubang Buaya as a coup d'etat and accused the PKI of being the mastermind. They also spread erroneous reports that the bodies, discovered at Lubang Buaya bore the marks of sexual torture, which they alleged was committed by women from Gerwani, which was linked to the PKI. To conduct its anti-PKI campaign, the army formed an alliance with civil society groups, which were opposed to the PKI, including religious communities and student groups. By mid-October 1965, the army had successfully begun to repress the PKI directly, or, as in Java and Bali, through the use of proxies, namely civilian militias drawn from other political parties or religious groups. Approximately half a million people were killed in the 1965-1966 massacres (Cribb 2001, 219). Amnesty International $(1977,41)$ estimates that, based on the compilation of several figures cited by Indonesian authorities, between 600,000 and 750,000 people were imprisoned for varying lengths of time. The PKI and associated mass organizations such as trade unions, and women, graduate, and student organizations were officially banned in March 1966.

With the rise of Suharto regime, there was a radical break with the past in Indonesian society, tied to the annihilation of PKI members and sympathizers. Under Suharto, Indonesia moved away from Sukarno's earlier preoccupations with independence, autonomy, and self-sufficiency (which was espoused, for example, in Sukarno's slogan, "standing on one's own two feet," "berdiri di atas kaki sendiri, berdikari”). Resuming relations with the West and reopening the country to foreign aid and investment, Suharto prioritized economic development and portrayed his regime, and the army in 
particular, as the savior of Indonesian people from the chaos and economic mismanagement of the former Sukarno era. Suharto also depoliticized Indonesian society by prohibiting political parties from being active on the local village level, declaring the "floating mass" doctrine. Social and political activism became severely circumscribed and fundamentally altered. The regime struggled with obtaining legitimacy after unseating Sukarno, which explains its preoccupation with disseminating narratives about its founding and importance. The regime established its own historical narrative through devices such as history curricula, textbooks, monuments, and museums (McGregor 2007). This narrative situates the military as the most important social actor that safeguarded the nation from external threats, including communism and radical Islam. To maintain the deep sentiment of anticommunism, the regime commemorated the "coup attempt" each year through a public holiday, ceremonies at Lubang Buaya, and television broadcasts of the government propaganda film entitled The Betrayal of the Thirtieth September Movement/PKI, reinforcing the message of the dangers of communism (Heryanto 2006, 6-7).

Former political prisoners were largely unable to counter these messages, because-following lengths of imprisonment varying from several months to more than twelve years, largely without trial-they emerged into a world in which the regime restricted their freedoms of movement, expression, and assembly. They were prohibited from holding publicly influential jobs, for example, as journalists and public servants. They were forced to report regularly to the authorities. They were not permitted to write, publish, or address gatherings and meetings. They were absent from public discourse, despite the sheer numbers of people who suffered imprisonment. Interviewees are therefore attempting to tell their story in the context of a strong regime-driven narrative, and trying to insert a sense of collective memory into the public history that exists about this past.

\section{GOVERNMENT POLICIES, MEMORIES, AND FORGETTING}

The fall of the regime in 1998 opened the way for interviewees to be able to speak out, but their ability and willingness to do so varied. Age or residual trauma posed difficulties for many survivors in rendering past experiences into a logical narrative. The basic failures and vulnerability 
of human memory, for example, rendered one interviewee "Leila" unable to tell me in 2010 of what she did as a full-time staff member of Gerwani in 1959. These were questions she had answered in 2007, and I returned to those questions as an opening to ask some followup questions regarding her personal life. ${ }^{4}$ She had plainly forgotten. I examined her face and could see that she was thinking very hard, but the memories did not come. Oei (2007), who confessed to feeling traumatized by his imprisonment and living through the mass killings, has fragmented memories about the killings around the south Malang area, based on his travels there trying to find evidence of the massacre. In relating an account of the violence of 1965, he borrowed images and memories from other recollections he had heard and from more contemporary events, such as the 2007 discovery of human remains at a housing complex near his current residence.

In a sense, remembering seemed to be also a precious commodity. Some survivors still felt fearful-and therefore unable to express openly about their past imprisonment-if they were less financially secure, or if they were living in small towns and villages. Those who lived in the cities and were living in comparably secure circumstances were more likely to have the confidence to discuss or even write about their past experiences of involvement in organizations and about how they were treated as former political prisoners. ${ }^{5}$

A further difficulty for the researcher in trying to "mine memories" is the need for former political prisoners to obscure the past in varying degrees. By criminalizing past political or social activism under the PKI umbrella, the Suharto regime helped remodel the way survivors felt about or remembered this activism. It was in their interest at times, as a group of marginalized people, to keep their personal history hidden. Those who were arrested in the mid-1960s in connection with their involvement in the political Left were interrogated, often under torture, about their involvement in the PKI or mass organizations. Some were then categorized into one of three categories: those deemed to have direct responsibility in the Thirtieth September Movement were classified into Category A; Category B was made up of those who had "indirect responsibility"; and Category C was for those with "looser connections" to the Movement (Amnesty International 1977, 22). Others who escaped categorization were supposed to be released, but in reality languished in prison for their association with left-wing organizations in general (ibid.). For those who were not clearly identifiable as party or mass movement leaders, 
their first recourse was to deny any association with the PKI. This denial, depending on the individual's circumstances, might constitute the detainee's first instance of distancing him/herself from the immediate past. The interrogators responded with torture to such denials, in order to extract "confessions." As Roosa $(2008,43)$ argues, the use of torture and the resulting production of untruths created new and false realities. Under torture, detainees at times agreed they were members of the PKI, which they later recanted. Sumanto (2007), who had been an inspector of technical schools and was a member of the Indonesian Technical Teachers' Association, recalled how under torture, one prisoner in Kalisosok prison in Surabaya agreed to "being a member of everything to make the torture stop." Nevertheless, prison administrators dutifully compiled interrogation reports, even when these reports were worthless, or were later strenuously rejected by the detainees concerned ${ }^{6}$ (Anderson 2010, xviii). The authorities' simplification of all forms of activism into one under the PKI banner erased the varied and complex life stories of the detainees and, in turn, their past involvement in the many social and political organizations that had thrived before the anti-PKI repression.

By grouping leftist mass organizations as part of the PKI, political activism in these organizations became synonymous with PKI membership. This was true in particular for members of unions affiliated with SOBSI, in which the PKI exercised significant leadership. In my interviews with former political prisoners, those who had been active in trade unions felt that while they organized alongside PKI members and sympathized with the party's aims, their union was not structurally related to the PKI. Sumanto was one individual who felt that his union activism had now become conflated with PKI activism. This was also the case for members of Gerwani, ${ }^{7}$ the People's Cultural Institute (Lembaga Kebudayaan Rakyat, or Lekra), and smaller organizations like the Indonesian Graduates' Association (Himpunan Sarjana Indonesia, or HSI) (Harsutejo 2007). The histories and missions of these organizations, often quite distinctive, therefore became blurred, diminishing understanding of Indonesian history and its diverse professional and activist organizations of the 1950s and 60s.

It was not only through imprisonment that individuals were forced to conform to the regime's association of all forms of activism with the PKI. As part of the anti-communist purges, many workplaces and institutions formed teams to screen out employees with communist sympathies. Employees who had been active in communist-linked 
unions were suspended or had their employment terminated for political reasons. ${ }^{8}$ Following a screening session led by the dean of his faculty, "Haryadi" (2007) was dismissed from his job as head of administration in the faculty of shipping at a technical college in Surabaya, because of his activism in the workplace union and for his known PKI sympathies. His screening and dismissal reinforced his workmates' perception of him as a PKI sympathizer. "Haryadi" found employment elsewhere, but a former colleague who was detained a few years later, turned him over to the authorities as a suspected communist. In 1969, "Haryadi" was captured in Jakarta. He spent around ten years in several prisons, first in East Java, then at the special detention camp on Buru Island in the Moluccas. His fate at the hands of the workplace screening program created the impression for his former colleague, that it was reasonable to pinpoint him as a communist.

After their release from prison or if they had successfully evaded capture, those who were persecuted used a range of strategies to survive, including assuming new names and new lives which helped obscure their pasts. One interviewee, Harsutejo, who had been a university lecturer, told me that after being in prison for six months from November 1965, he left his hometown for fear of being imprisoned again because of the political circumstances that were in flux (Harsutejo 2007). His goal was to reach Jakarta, the capital in which he hoped to begin a new life by obscuring his past and his identity. Harsutejo's family had had long-term involvement in various leftist organizations. Several of his relatives were killed as a result in several towns in East Java, including Blitar and Surabaya. As a former detainee with leftist family connections, Harsutejo was a marked man, and it was not easy for him to get the necessary papers to move immediately to Jakarta. He had new identity papers made, altering his name slightly to obscure his real identity. He moved to the provincial capital Surabaya first, then to Jakarta. In Jakarta, he found work in a bank, where he ended up working for over twenty years. He was careful not to appear too qualified when first applying for the job. Unusual job applicants with something to hide were common in this period, because many people were on the move, usually escaping into the larger cities, to survive.

"Achmad" (2007) was a PKI leader in one of the cities of East Java. He also escaped to Jakarta to avoid capture. In November 1967, he was arrested there, after an acquaintance reported him to the authorities. In 1970, he was transferred to the city where he had been politically active, continually under threat of being tried for involvement in the 
Thirtieth September Movement, but this never eventuated. When he was released in 1979, he changed his name and immersed himself in a new profession that he had learned while in prison, acupuncture. He rose to become a respected member of the national professional association for acupuncture. However, until his involvement in a victims' advocacy group in 1998, his past as a PKI leader lived only in the minds of a handful of those who knew him before the repression. It was only a referral from another former political prisoner that led me to a meeting with him. He had invented a whole new life for himself. After the fall of Suharto, however, he felt it was possible to become involved in a human rights advocacy group for victims of "1965." In our interview, he took great pains to point out that he had only been a journalist for the PKI's Harian Rakyat (People's Daily), rather than admitting to being the PKI secretary of a large city in East Java. Had I known of his real position, the interview I conducted with him would have been different, but he died before I could re-interview him. After his death, I resorted to speaking with those who had known him as a political leader, and to studying his speeches and articles in PKI publications, published under his real name. Therefore, in using these strategies of hiding their political past, interviewees are constrained in what direct information they could impart about their personal activism.

Those who were persecuted at times drastically altered their professions in the hope of avoiding detection. "Rachmat" (2007) was qualified as a teacher, but was working in Jakarta at the Youth Bureau's (Biro Pemuda) Information Section in October 1965, where he liaised with various youth organizations, such as the branches of the Indonesian Students' Association (Perhimpunan Pelajar Indonesia, or PPI) in several countries. ${ }^{9}$ They published newsletters, collected press clippings about youth issues, and helped youth organizations hold activities, such as tree planting and singing competitions. "Rachmat" was a member of the education union (Serikat Staf Pendidikan). Like others at his workplace, he was screened for communist sympathies. In March 1966, the Department of Education decided he was to be stood down. Unemployed people with high qualifications aroused suspicions and so "Rachmat" kept a low profile by seeking work well below his qualifications in which he thought he would attract little attention. "Rachmat" told others he had only completed third grade to enable him to get work as a newspaper deliverer. He then resorted to selling lottery coupons in the street and selling cooking oil from house to 
house, before becoming a tiler. He characterized this time in his life as one of "feeling as if [he] was on the edge of the precipice, always about to fall at each moment." His concern was how to earn money without arousing suspicion about his background, and how to stay out of prison. He said, "I did not go to jail, but I experienced enormous inner suffering (penderitaan batin).” His successive occupations took him further and further away from his earlier passions about learning, particularly studying, writing, and teaching about Sukarno's nationalist ideas. ${ }^{10}$ In the mid-1980s, much to his joy, "Rachmat" obtained work as an emergency teacher, as close as he could get to his earlier training. On a concrete level, therefore, the regime was altering the material circumstances and mode of existence for this group of people, thereby distancing them from past ideals and thinking. It becomes difficult to convey past activism when such a distance, both temporal and physical, exists in the present day circumstances in which these memories are recounted.

During the 1980s, the regime introduced the "clean self, clean environment" ("bersih diri, bersih lingkungan") policy, in which public servants and those holding public office must demonstrate that they and their family had no past links with the PKI. By doing so, the regime also ensured a deeper submersion of the past by casting a wide net to include the descendants and relatives of former political prisoners. Families took great pains to hide their "unclean" past from children and grandchildren. ${ }^{11}$ The regime's persecution of former political prisoners fostered a "community" around a shared stigma and through the range of discriminations they suffered. Due to the stigma, some families who had family members incarcerated, preferred to marry among themselves, and, in turn, married their children within the "community," as it was easier than having to explain their past to others and risk being shunned afterwards. ${ }^{12}$ Indonesian human rights campaigning in the 1990s has also influenced the formation of a "community" of victims.

\section{POST NEW ORDER}

The secrecy and rather sinister pall surrounding the PKI during three decades of Suharto rule ensured that when the regime fell in May 1998, there was a great interest in both the "coup attempt" as well as the aftermath, the bloody repression of the PKI. Victims' groups sprang 
up, which were also related to other cases of the regime's human right abuses, such as the forcible disappearance of young activists in 1998. Popular histories critical of the regime began to be published, although official histories proved harder to shift. ${ }^{13}$ Former political prisoners, victims' groups, and some human rights and research institutes published and discussed the experiences of victims in the 1965-1966 violence (e.g., Sulami 1999; Sudjinah 2003; Moestahal 2002; Siwirini 2010; Susanti 2006; Setiawan 2006; cf. Hearman 2009; Watson 2006). Indeed, as Kay Schaffer and Sidonie Smith (2004,17-18) have shown, the use of life narratives in human rights advocacy has generally become more prevalent since the end of the Cold War; interest in life story narratives has coincided with the outbreak of catastrophes, the breakup of nation-states, growing insecurity, and an increasing strengthening of rights discourse since the 1980s. Yet Elizabeth Oglesby $(2007,79)$, in writing about Guatemala's experiences of overcoming the civil war, cautions that truth commission-style narratives, those preoccupied with securing particular human rights outcomes, "result in a narrowing of the range of narratives through which the past is understood." Such accounts of violence confirm that "the war produced victims, but it does not elucidate that in the majority of cases, these victims also had identities as social actors, as members of organizations (some revolutionary, some not) involved in projects of social change." The same difficulties with discussing political activism can also be found in survivor accounts in Indonesia.

Aspirations for justice in prisoner memoirs suggest how little progress Indonesia has made in improving the lives of survivors of human rights abuses, and in revising the historical narrative about 1965. ${ }^{14}$ Former political prisoners' life stories emphasize suffering in prison or afterwards, but deal little with the world they inhabited before imprisonment. Perhaps the authors were mindful that in the first years of the democratic era, the public was not quite ready to accept discussions of leftist political activism of the 1960s (Sulami 1999; Sudjinah 2003; Siwirini 2010). Ariel Heryanto (2006, 24) has examined how the New Order's historical narrative, and indeed anti-communism itself, has successfully survived the demise of the regime. The population, particularly those born after 1965, were either estranged from or ignorant about alternative narratives of Indonesian history or of the events that had occurred prior to October 1965. The (auto-) biographies therefore contain simple messages, intent on breaking down the strongest stereotypes of communists as national 
traitors and atheists. They do this, for example, by showing the extent to which former political prisoners had actively committed themselves to the independence struggle in the 1940s, and that they practiced their religion (Moestahal 2002; Soepardjan 2004).

In the absence of any post-Suharto consensus on what occurred at Lubang Buaya and why it occurred, former political prisoners focus their campaign efforts on promoting the view that the PKI-and in turn, mass organizations associated with the PKI-was innocent of involvement in the Thirtieth September Movement. ${ }^{15}$ In this quest, some former political prisoners were therefore unhappy at historian John Roosa's conclusion in his 2006 book, that chairman D. N. Aidit and the PKI's Special Bureau had been involved in the Thirtieth September Movement (Iskandar 2007). However, Roosa's work was highly reliant on evidence gathered through interviews with leftist activists and leaders, thus showing that memories held about this period differed widely, owing to the variety of people who became political prisoners. One former political prisoner in East Java recalled that the SOBSI union leadership instructed him, following the failure of Thirtieth September Movement in Jakarta, to take over his industrial plant to counter this failure (Soepardjan 2004, 69). That survivors have at last had a chance to argue their innocence is a progressive step, but we can also ask whether the formation of a "collective memory" among survivors, in turn, is reimposing a different kind of historical orthodoxy, which some memories in fact cannot conform to.

\section{CREATING A MULTIPLICITY OF NARRATIVES ABOUT THE PAST}

The documented extent to which the official narrative of 1965 has been distorted, and the suppression of any public discussion during the New Order regime, make it important to create a multiplicity of narratives about this past. The National Human Rights Commission concluded in July 2012 when handing down a report into the 1965-1966 "incident" ("peristiwa 1965-1966") that the violence represented a gross violation of human rights. Yet responses to this report indicated that sections of the population still adhere to the virulent anti-communism which had been propagated by the New Order regime. Coordinating minister for Politics, Human Rights and Security, Djoko Suyanto argued that "the anti-communist purge was justified, as it was aimed at 'saving 
the country" (Aritonang 2012). Physical evidence of the violence, such as human remains buried in mass graves, has deteriorated as a result of the tropical climate. ${ }^{16}$ Prisons and former detention centers have been destroyed or the buildings' functions have changed. ${ }^{17}$ The disappearance of these forms of evidence underscores the importance of creating new narratives about the past.

My own concern with documenting the lives of those who had been imprisoned is a small example of creating new ways of reading the past. For instance, I show how intricately activism in the 1950 s and 1960s was bound up, not necessarily with the PKI, but rather with the whole context of a newly independent Indonesia and the desire of Indonesians to modernize the country. Campaigns for literacy, economic development, and the incorporation of West Irian into Indonesian territory, for example, enjoyed widespread public support. To undo the taboos surrounding the PKI and those who had been associated with it, it is necessary to unsettle the regime's association of activism purely with the PKI. The Indonesian peace movement for example, or indeed many other forms of social and political activism, was not just the domain of communists. ${ }^{18}$ Many of those labeled as PKI members were only sympathizers or fellow travelers. Rather than seeing communists as somehow unique in being politically active, I argue that activism was not the monopoly of communists as the New Order regime portrayed it. The army repression, however, destroyed all political and social activism and organization independent from the government.

Memory and its capacity to represent events are subject to the ravages of time, trauma, and the context, both social and political, in which it is situated and voiced. The act of testifying takes place in the present, post-New-Order historical context; however, the memories need to be anchored within the historical context in which the acts related to the memories occurred. As Jelin (2003) writes, in cautioning researchers against searching for or reinventing a new historical orthodoxy through the use of memories, "there will always be other stories, other memories and alternative interpretations." In working with memories, contestations, conflicts, and different memories will inevitably arise, contingent to the political struggle occurring over the events that these memories deal with. Steven Stern $(2006,7)$ has highlighted these memory struggles in the case of Chile, where a section of the population remembered the military coup against Salvador Allende in 1973 as a moment of salvation for them. Similarly 
in Indonesia, those who were members of Nahdlatul Ulama (NU), who were political rivals of the PKI in the 1960s, remembered the anti-PKI repression as their deliverance from the communists. But as Katharine McGregor (2009) has shown, this memory orthodoxy is coming under attack from young people within NU itself. ${ }^{19}$ Working with memory to re-knit the past is one way in which researchers can contribute skills and resources to survivors of political violence, but such an activity is also a contribution towards historical truthfulness, by amplifying the voices that "reach" us from the past and by contributing to conversations about that history across different social, temporal, and spatial settings (Morris-Suzuki 2005, 241).

The failure of the state to deal with this past has opened the way for many non-state initiatives, such as in publishing, film production, and memorialization. Two Balinese examples of the latter are the 2007 cremation ceremony (without any remains to cremate) for former Balinese governor Anak Agung Sutedja, who disappeared in November 1965, and the creation of sites such as Taman 1965, a memorial in Badung district to victims of the killings (Vickers 2010, 55-57; cf. Dwyer 2009). Every Thursday afternoon, since January 2006, victims of different cases of human rights abuse and their supporters stand outside the Presidential Palace in Jakarta, holding black umbrellas in a silent protest (Saragih 2011). In Indonesia's relatively fertile publishing environment, there continues to be at least a few new works each year, which deal with the history or the survivors of this violence. ${ }^{20}$ Some former political prisoners, such as Putu Oka Sukanta and Harsutejo, have become well-known writers and editors, and are speaking publicly about their experiences. Harsutejo's own forthcoming memoir includes a frank discussion of political activism in the 1950s and 1960s. At the same time, this memoir rehumanizes the political prisoner, in restoring him into the framework of family life, work, and study, although all these became very difficult after October 1965. More modest in his public impact is "Rachmat," who had worked at the Youth Bureau and then resorted to selling newspapers and lottery tickets on the street. He began, at the end of the New Order regime, to write articles about Sukarno's ideas, which he then published as small booklets. ${ }^{21} \mathrm{He}$ also compiled a book of Indonesian nationalist and regional songs, believing such an effort would contribute to greater national awareness about the past (Lembaga Putra Sang Fajar n.d.). All these efforts show the enthusiasm of former political prisoners in trying to participate in public life, by whatever means are at their disposal. For so many who 
are in their twilight years, it is a race to make a difference, while there is still time.

\section{NOTES}

1 The Department of Education and Culture (Kementerian Pendidikan dan Kebudajaan, or Kemendikbud) estimated this to be 35 million people.

2 Gerwani was Indonesia's largest women's organization.

3 Mackie (2005) argues that while seeds for the NAM were sown in Bandung, the initiative had moved from Indonesia and the other four countries that initiated the Bandung Conference (Pakistan, Burma, India, and Ceylon; later, Sri Lanka), to Egypt and Yugoslavia, with Nasser and Tito playing leading roles at the NAM's conference in 1961. While both Sukarno and Nehru attended the Belgrade conference, the focus had shifted away from Afro-Asianism. Only fifteen of the 29 Bandung attendees were there in Belgrade.

$4 \quad$ All names enclosed within quotation marks are pseudonyms.

5 These observations are drawn from interviews on perceptions of former political prisoners about the proposed Indonesian Truth and Reconciliation Commission were conducted in April and May 2007 in Java and Bali, and are compiled in Hearman (2007).

6 Tan Swie Ling, who hid PKI Politburo member Sudisman and was arrested for doing so, rejected in court the information contained in his interrogation report on the grounds it was extracted under torture.

7 Wieringa (2002) suggests that the PKI determined the political agenda of Gerwani and sidelined feminist issues in preference for the organization's support for communism.

8 On the impact of the screening policy, see the District Administrator (Bupati)'s letter (1975) to Assistant to the Governor of East Java, on the reinventarization of personnel involved in the Thirtieth September Movement. According to the letter, the screening team deemed 157 local government personnel in Bangkalan District Administration to have been "involved" in the Thirtieth September Movement in varying degrees. Thirty-four of them were sacked and 123 were allowed to continue to work. Screening teams were told they needed to place civil servants into C1, $\mathrm{C} 2$, and $\mathrm{C} 3$ categories, and those in $\mathrm{C} 1$ were to be dishonorably discharged, while $\mathrm{C} 2$ and $\mathrm{C} 3$ could continue working. Workers who were allowed to continue had to "receive guidance" and have their behavior monitored. Instructions were issued through a 1975 decree of the Commander of the Operational Command to Restore Security and Order (Keputusan Panglima Komando Operasi Pemulihan Keamanan dan Ketertiban Nomor KEP-03/KOPKAM/VIII/1975 tentang Pelaksanaan Keputusan Presiden Republik Indonesia Nomor 28 tahun 1975), East Java Provincial Archives.

9 The PPI in the early to mid-1960s had branches in different countries, such as Bulgaria, Germany, Czechoslovakia, and the USSR (Mrs. S. B. 2011).

10 According to "Rachmat," he had written a series of articles on Sukarno's Political Manifesto (Manifesto Politik) for the magazine Panca Warna.

11 "Ali Sabil" (2007) did not tell his wife that he had been a political prisoner until 2005, shortly before her death. "Dodi" (2007) related to me how he, as the son of two former political prisoners, had still, at the time of the interview, not told his children about their grandparents' past.

12 For example "Wiek" (2007), who was a regular prison visitor to former Gerwani leader "Tuti," became related to "Tuti" when "Wiek's" brother married her son. Some women who were stigmatized as Gerwani members might have been assaulted or raped in prison, which made it difficult for them to marry once out of prison; they then married men who had been political prisoners or politically stigmatized themselves.

13 Historical works critical of the previous regime include that of Warman Adam Purwanto (2005), which problematizes Indonesian historiography of pivotal national events such as the 1965-1966 killings. On shifting official history, a team of historians, with Warman Adam involved, created a new history education curriculum in 2004 which removed associations of the PKI with the Thirtieth September Movement. In 2007, the Attorney-General collected all history textbooks written under this new curriculum and ordered that they be destroyed. See Jakarta Post 2007. 
14 In 2005, former political prisoners failed in a class action against five Indonesian presidents and the state of Indonesia for neglecting to uphold the human rights of former political prisoners. (See Hutabarat 2011.) Indonesia has also failed to establish a Truth and Reconciliation Commission. Ironically, at the urging of non-government and human rights organizations, in December 2006, the Constitutional Court examined the 2004 Truth Commission Law and the Court declared that certain provisions, such as those granting amnesty to perpetrators, were unconstitutional. It further ruled that the law itself was therefore unconstitutional.

15 Roosa and Ratih $(2008,180)$ argue that the persistence of the New Order regime's version about the Thirtieth September Movement, even after the regime has ended, is the result of historians' unsuccessful attempts in coming up with a credible alternative.

16 Sections of the community are opposed to the exhumation of mass graves and the reburial of remains in their area of those considered to be "communist," as one incident in 2000-2001 in Central Java showed. See Heryanto (2006, 1-2).

17 One example of the destruction of historic prisons is that of Kalisosok Prison in Surabaya. In 1998, the prison was listed as one of 163 significant historic sites in Surabaya (Kuncarsono 2010).

18 For example, Ratu Aminah Hidayat was an activist involved in the women's and peace movements but was not a PKI member. She was the head of Indonesia's Peace Committee, a chapter of the World Peace Council. Utami Suryadharma, also not a communist, was the head of Afro-Asian People's Solidarity Organization's Women's Committee (Wieringa 2002, 187).

$19 \mathrm{NU}$ is Indonesia's largest Islamic organization today, but it was a political party in the 1960s all the way until 1971, when under the New Order, political parties were amalgamated into three parties: the government electoral vehicle Functional Groups (Golongan Karya, or Golkar), the United Development Party (Partai Persatuan Pembangunan, or PPP), and the Indonesian Democratic Party (Partai Demokrasi Indonesia, or PDI).

20 Other than those already mentioned, these include Nugroho (2008) on mass conversions to Christianity as a result of the regime change; a history of Lekra in Yuliantri and Dahlan (2008); the autobiography of singer Affandi (2010); and a history of the women's prison in Plantungan, Central Java in Lestariningsih (2011). This set of examples show the diversity of works dealing with 1965.

21 These booklets were in a series called Readings for the People (Bacaan untuk Rakyat).

\section{REFERENCES}

Achmad. 2007. Interview by author, Malang, 10 May.

Affandi, Nani Nurani. 2010. Penyanyi istana: Suara hati penyanyi kebanggaan Bung Karno. Yogyakarta: Galang Press.

Aidit, D. N. 1965. Quoted in Harian Rakjat, 20 Aug. Cited in Mortimer 1974.

Ali Sabil. 2007. Interview by author, Jakarta, 28 Apr.

Amnesty International. 1977. Indonesia: An Amnesty International report. London: Amnesty International.

Anderson, Benedict R. 2010. Seperti minum air pegunungan. In G30S 1965, Perang dingin and kehancuran nasionalisme: Pemikiran Cina jelata korban Orba, Tan Swie Ling, xvii-xxv. Jakarta: Komunitas Bambu and LKSI.

Anderson, Benedict R. and Ruth T. McVey, with Frederick Bunnell. 1971. A preliminary analysis of the October 1, 1965, coup in Indonesia. Ithaca, NY: Modern Indonesia Project, Cornell University.

Aritonang, Margareth S. 2012. 1965 mass killings justified: Minister. Jakarta Post, 1 October. Online, http://www.thejakartapost.com/news/2012/10/01/1965-mass-killingsjustified-minister.html, accessed 3 Oct. 2012.

Bupati of Pamekasan. 1975. Letter to Assistant to the Governor of East Java, Pamekasan no. 167/4/UP/Rhs. Arsip Jawa Timur. 
Cribb, Robert. 2002. Unresolved problems in the Indonesian killings of 1965-66. Asian Survey 42.4 (Jul./Aug.): 550-63.

Cribb, Robert. 2001. Genocide in Indonesia: 1965-66, Journal of Genocide Research 3.2: 219-239.

Crouch, Harold. 1988. The army and politics in Indonesia. Ithaca, NY: Cornell University Press.

Dodi. 2007. Interview by author, Jakarta, 27 Apr.

Dwyer, Leslie. 2009. A politics of silences: Violence, memory, and treacherous speech in post-1965 Bali. In Genocide: Truth, memory, and representation, ed. Alexander Laban Hinton and Kevin Lewis O'Neill, 113-146. Durham, NC: Duke University Press.

Gilmore, Leigh. 2001. The limits of autobiography: Trauma and testimony. Ithaca, NY: Cornell University Press.

Graham, Duncan. 2004. Hidden treasures. Inside Indonesia, Apr.-Jun. Online, http://www insideindonesia.org/weekly-articles/hidden-treasures, accessed 27 Sep. 2012.

Halbwachs, Maurice. 1992. On collective memory. Trans. and ed. Lewis A. Coser. Chicago: University of Chicago Press.

Halbwachs, Maurice. 2007. From the collective memory. In Theories of memory: A reader, Michael Rossington and Anne Whitehead, 139-143. Edinburgh: Edinburgh University Press.

Harsutejo. Forthcoming. Keluarga abangan. Bandung: Ultimus.

Harsutejo. 2007. Interview by author, Jakarta, 30 Apr.

Haryadi. 2007. Interview by author, Jakarta, 28 Jul.

Hearman, Vannessa. 2007. Fighting to tell their stories: 1965 ex-political prisoners and the Indonesian truth and reconciliation commission. Paper presented at In Search of Reconciliation and Peace in Indonesia and East Timor, National University of Singapore, 18-20 July.

Hearman, Vannessa. 2009. The uses of memoirs and oral history works in researching the 1965-66 Political Violence in Indonesia. International Journal of Asia-Pacific Studies 5.2 (Jul.): 21-42.

Heryanto, Ariel. 2006. State terrorism and political identity in Indonesia: Fatally belonging. Abingdon: Routledge.

Hill, David T. 2010. Indonesia's exiled left as the cold war thaws. Review of Indonesian and Malaysian Affairs 44.1 (Jul.): 21-51.

Hutabarat, Restaria F. 2011. Stigma 65: Strategi mengajukan gugatan class action. Jakarta: Yayasan Pustaka Obor Indonesia.

Jakarta Post. 2007. Book burning a "bonfire of liberty," 8 Aug. Online, http://www .thejakartapost.com/news/2007/08/08/book-burning-039bonfire-liberty039.html -0, accessed 15 Mar. 2010.

Jelin, Elizabeth. 2003. State repression and the labors of memory (Contradictions of modernity). Trans. Judy Rein and Marcial Godoy-Anativia. University of Minnesota Press. Kindle edition, Amazon.com.

Kementerian Pendidikan dan Kebudajaan Republik Indonesia. 1952. Dari buta huruf ke autonomie. Indonesia: Kementerian Pendidikan dan Kebudajaan.

Kuncarsono. 2010. Kidung duka di penjara Kalisosok. Surya, 8 Apr. Online, http://www .surya.co.id/2010/04/08/kidung-duka-di-penjara-kalisosok.html, accessed 2 Jun. 2010 .

Laub, Dori. 1995. Truth and testimony: The process and the struggle. In Trauma: Explorations in memory, ed. Cathy Caruth, 61-75. Baltimore: Johns Hopkins University Press.

Leila. 2007. Interview by author, Jakarta, 26 Apr.

Leila. 2010. Interview by author, Jakarta, 10 Nov.

Lembaga Putra Sang Fajar. n.d. Membangkitkan kembali lagu-lagu nasional di kalangan rakyat. Jakarta: Lembaga Putra Sang Fajar.

Lestariningsih, Amurwani Dwi. 2011. Gerwani: Kisah tapo/ wanita dari Plantungan. Jakarta: Gramedia. 
Leydesdorff, Selma, Graham Dawson, Natasha Burchardt and T.G. Ashplant. 1999. Introduction: Trauma and life stories. In Trauma and life stories: International perspectives, ed. Kim Lacy Rogers, Graham Dawson, and Selma Leydesdorff, 1-26. London: Routledge.

Mackie, Jamie. 2005. Bandung 1955: Non-alignment and Afro-Asian solidarity. Singapore: Editions Didier Millet.

Martyn, Elizabeth. 2005. The women's movement in post-colonial Indonesia: Gender and nation in a new democracy. London: RoutledgeCurzon.

Nora, Pierre. 1996. Realms of memory, vol. 1: Conflicts and divisions, ed. Lawrence Kritzman. New York: Columbia University Press.

McGregor, Katharine E. 2007. History in uniform. Singapore: Singapore University Press.

McGregor, Katharine E. 2009. Confronting the past in contemporary Indonesia: The anticommunist killings of 1965-66 and the role of the Nahdlatul Ulama. Critical Asian Studies 41.2: 195-224.

Moestahal, Achmadi. 2002. Dari Gontor ke Pulau Buru. Yogyakarta: Syarikat.

Morris-Suzuki, Tessa. 2005. The past within us: Media, memory, history. London: Verso.

Mortimer, Rex. 1974. Indonesian communism under Sukarno 1959-65. Ithaca, NY: Cornell University Press.

Nugroho, Singgih. 2008. Menyintas dan menyeberang: Perpindahan massal keagamaan pasca 1965 di pedesaan Jawa. Yogyakarta: Syarikat.

Oei Hiem Hwie. 2007. Interview by the author, Surabaya, 2 Aug.

Oglesby, Elizabeth. 2007. Educating citizens in postwar Guatemala: Historical memory, genocide and the culture of peace. Radical History Review 97 (Winter): 77-98.

Rachmat. 2007. Interview by author, Jakarta, 28 Jul.

Roosa, John. 2006. Pretext for mass murder: The September 30th movement and Suharto's coup d'etat in Indonesia. Madison: University of Wisconsin Press.

Roosa, John. 2008. The truths of torture: Victims' memories and state histories. Indonesia 85 (Apr.): 31-50.

Roosa, John and Ayu Ratih. 2008. Sejarah lisan di Indonesia dan kajian subjektivitas. In Perspektif baru penulisan sejarah Indonesia, Henk Schulte Nordholt, Bambang Purwanto, and Ratna Saptari, 177-200. Jakarta: Yayasan Obor Indonesia and KITLV Jakarta; Denpasar: Pustaka Larasan.

Saragih, Bagus B. T. 2011. Human rights abuses: 200 weeks on, victims remain steadfast in search for justice. Jakarta Post, 10 March. Online, http://www.thejakartapost .com/news/2011/03/10/human-rights-abuses-200-weeks-victims-remain-steadfastsearch-justice.html, accessed 3 Oct. 2012.

S. B. 2011. Discussion with author, Berlin, 29 Aug.

Schaffer, Kay and Sidonie Smith. 2004. Human rights and narrated lives: The ethics of recognition. New York: Palgrave Macmillan.

Setiawan, Hersri. 2006. Kidung untuk korban: Dari tutur sepuluh narasumber eks-tapol. Solo: Pakorba and Pustaka Pelajar.

Siwirini, Sumiyarsi. 2010. Plantungan: Pembuangan tapol perempuan. Yogyakarta: PUSdEP, Sanata Dharma University.

Soepardjan, Adam. 2004. Mendobrak penjara rezim Soeharto. Yogyakarta: Ombak.

Stern, Steven J. 2006. Remembering Pinochet's Chile: On the eve of London 1998. Durham and London: Duke University Press.

Sudjinah. 2003. Terempas gelombang pasang: Riwayat wartawati dalam penjara Orde Baru. Jakarta: Pustaka Utan Kayu.

Sulami. 1999. Perempuan kebenaran penjara. Jakarta: Cipta Karya.

Sumanto. 2007. Interview by author, Blitar, 10 May.

Susanti, Francisca Ria. 2006. Kembang-kembang genjer y ca Perempuan kebenaran penjara pitalization. n.p.: Lembaga Sastra Pembebasan. 
Vickers, Adrian. 2010. Where are the bodies? The haunting of Indonesia. The Public Historian 32.1: 55-57.

Warman Adam, Asvi and Bambang Purwanto. 2005. Menggugat historiografi Indonesia. Yogyakarta: Ombak.

Watson, C. W. 2006. Of self and injustice: Autobiography and repression in modern Indonesia. Leiden: KITLV Press.

Wertheim, W. F. 1970. Suharto and the Untung coup: The missing link. Journal of Contemporary Asia 1.1 (1 Jan.): 50-57.

Whitehead, Anne. 2009. Memory. London: Routledge.

Wiek. 2007. Interview by author, Malang, 30 Jul.

Wieringa, Saskia. 2002. Sexual politics in Indonesia. London: Palgrave.

Yuliantri, Rhoma Dwi Aria and Muhidin M. Dahlan. 2008. Lekra tak membakar buku: Suara senyap lembar kebudayaan Harian Rakjat, 1950-1965. Yogyakarta: Merakesumba.

VANNESSA HEARMAN is a doctoral researcher at the University of Melbourne. Her thesis deals with the several stages of the violent transition to Suharto's New Order regime in East Java (1965-1968). Her research uses an oral history approach to examine the mass killings, imprisonment, and other violence against members and sympathizers of the Indonesian Communist Party. <vhearman@gmail.com> 